\title{
USOS E COSTUMES: SERIA POSSÍVEL VOLTARMOS AO VELHO GORAÇÃO DO DIREITO COMERCIAL?*
}

\author{
USES AND CUSTOMS: WOULD WE BE BACK TO THE OLD HEART \\ OF COMMERCIAL LAW?
}

\author{
Alan Pereira DE ARAúJo**
}

RESUMO: O presente artigo visa examinar, em linhas gerais, a disciplina jurídica dos usos e costumes no direito privado, especialmente no direito comercial/empresarial, partindo de sua análise no ordenamento pátrio, sem prejuízo de alguma contribuição oferecida pelo ordenamento estrangeiro. Investiga-se a possível compatibilidade ou aptidão dos usos e costumes para estimular o desenvolvimento do comércio nos dias atuais.

Palavras chave: Usos e costumes, direito comercial, lex mercatoria.
ABSTRACT: This article aims to examine, in general terms, the legal regulation of customs and traditions in private law, particularly commercial law/Business, from its analysis on parental order, without prejudice to any contribution made by foreign order. We investigate the possible compatibility or suitability of customs and traditions to encourage the development of trade today.

Keywords: Customs and traditions, commercial law, lex mercatoria.

* Artículo recibido el 26 de septiembre de 2017 y aceptado para su publicación el 24 de noviembre de 2017.

** Procurador federal. Mestre em direito. Pós-graduado em direito processual civil e em direito público.

Boletín Mexicano de Derecho Comparado, nueva serie, año L, núm. 151, enero-abril de 2018, pp. 227-262. 
SumÁRIO: I. Introdução. II. Conceito de usos e costumes. Generalidades. III. Usos e costumes no direito brasileiro. IV. Usos e costumes em alguns diplomas estrangeiros. V. Seria possivel voltarmos ao velho coração do direito comercial? VI. Conclusão.

VII. Referências.

\section{INTRODUÇÃO}

Ao investigar-se, no ano que passou, o instigante tema das sociedades anônimas simplificadas, objeto de um outro estudo, tivemos contato com artigo elaborado por Marcelo Andrade Féres (2008), onde este autor fazia menção ao respeitado doutrinador argentino Efraín Hugo Richard (2002), que sustentava, diante da crise por que passa o comércio, dever-se-ia voltar ao velho coração do Direito Comercial. Nas palavras do ilustre jurista portenho, Professor Emérito da Universidade Nacional de Córdoba, "debe volverse al viejo corazón del derecho comercial: los usos y costumbres como ética de los negocios, y la justicia inmediata para devolver la riqueza al circuito económico".

Esta afirmação apaixonada motivou as seguintes reflexões acerca da possibilidade ou não de voltar-se ao velho coração do direito comercial como forma de estimular o tráfego comercial. Para tanto, na primeira parte deste trabalho, conceituar-se-á usos e costumes, analisando-se, em seguida, seu regramento e valor no ordenamento brasileiro. Após, far-se-á referência aos usos e costumes em alguns diplomas estrangeiros, mais próximos à realidade brasileira. Por fim, enfrentar-se-á a questão proposta em tópico específico, verificando-se se existe espaço ou não para a utilização dos usos e costumes no mercado globalizado, onde se fala em uma nova lex mercatoria. A conclusão arremata as reflexões desenvolvidas.

A pesquisa realizada foi bibliográfica, enriquecida com a coleta de jurisprudência ilustrativa, escassa por sinal, do Superior Tribunal de Justiça, corte responsável por uniformizar a interpretação da lei federal em todo o Brasil. Adotou-se metodologia predominantemente histórico-jurídica, acompanhada, sempre que possível, daquela sistêmico-reflexiva.

Acredita-se que os usos e costumes, nos dias atuais, ainda não perderam sua importância para o comércio, especialmente o internacional. 


\section{Conceito De usos E COSTUMes. GeneralidAdes}

Iniciando o presente estudo, José Náufel (1963, pp. 130 e 131) conceitua o costume como sendo "o direito não escrito, o que se baseia na prática longamente observada em determinadas relações, o uso consagrado por todos, a praxe aceita unanimemente". Costumeiro ou consuetudinário seria, então, algo originário ou estabelecido pelo costume. Mais adiante em sua obra, ensina o autor (ibidem, p. 358) serem os usos e costumes "práticas habituais em determinado lugar, com natureza de normas gerais, que suprem a omissão da lei e se incorporam ao direito consuetudinário".

Com boa técnica, Olavo Acyr de Lima Rocha (1975, pp. 271 e 272) diferencia os usos sociais (de etiqueta, cortesia, moda, etc), que não são obrigatórios do ponto de vista jurídico, dos usos convencionais, que são usos da atividade negocial, encontrados no comércio como práticas gerais, locais ou profissionais informais, permeadas de boa-fé e que contribuem para interpretar e completar a vontade das partes. Tais seriam, por exemplo, os usos relativos à locação de prédios, de serviços, contratos de trabalho, venda civil ou comercial, sociedade, cheques, operações de bolsas, de armazéns gerais, contratos marítimos, testamentos, que, em muitos casos, se transformam em regras de direito objetivo pela substituição gradual da vontade dos particulares pela vontade comum e de conjunto, criando o sentimento geral da necessidade jurídica.

Marta Vinagre (1988, p. 111), entretanto, diferencia usos de costumes, reconhecendo a distinção entre as figuras, embora alguns autores vislumbrem sinonímia entre os termos ou se refiram aos institutos englobadamente. Segundo a autora, "uso é a repetição de atos, a reiteração da conduta", ao passo que o costume "vem a ser a regra que do uso decorre", de sorte que "há usos que se transformam nos costumes e que formam o direito consuetudinário".

A doutrina civilista normalmente observa nos costumes dois elementos que, conjugados, levariam à sua obrigatoriedade: um objetivo, externo, consistente na prática uniforme e reiterada de certos atos e outro subjetivo, interno, psicológico, correspondente à convicção jurídica, à certeza da imprescindibilidade da norma, ${ }^{1}$ sendo que, em relação à lei, o costume

1 Nesse sentido, Clóvis Beviláqua (2001, pp. 64 e 65) ensinava que "destacam-se no costume dois elementos: o externo, que é o uso e observância constante, e o interno que é a opinio necessitatis, a convicção de que a norma estabelecida funciona como lei, pela necessidade, 
pode apresentar-se como praeter legem (tem cunho supletivo e só intervém na ausência ou omissão da lei), secundum legem (preceito não contido na norma, mas reconhecido e admitido com eficácia obrigatória) e contra legem (se revela como norma contrária à lei). ${ }^{2}$

Usos e costumes, via de regra, são estudados dentro das fontes do direito comercial, hoje direito empresarial. A este respeito, João Eunápio Borges (1964, p. 70) afirmava que "como as de qualquer direito, são fontes do Direito Comercial a lei e o costume," destacando o jurista que o costume jurídico propriamente dito constitui fonte do Direito paralela à lei, já que provem do povo, porém é fonte extinta ou que tende a se extinguir.

Para Haroldo Verçosa (2011, p. 130), os usos e costumes "têm o peso de norma jurídica e correspondem a práticas criadas ao longo do tempo pelos comerciantes, as quais se tornam de aplicação geral e de ampla aceitação em determinados mercados". Acrescenta que, hoje, suas referências mais abrangentes estão nos artigos 111 e 113 do Código Civil em vigor.

De seu lado, esclarece José Jairo Gomes (2006, p. 40) que, ainda hoje, os costumes são considerados fontes subsidiárias do direito, ${ }^{3}$ ao lado da analogia e dos princípios gerais, conforme prescreve o artigo 4o. da LINDB (nossa conhecida Lei de Introdução ao Código Civil), o que se deve ao reconhecimento da incompletude do sistema jurídico, o qual, naturalmente, não contém solução para todos os problemas que surgem na vida social.

Contudo, usos e costumes não são apenas fontes do direito.

que há de regularizar o caso a que ela se refere, pelo modo nela estabelecido". Ronaldo Poletti (2006, p. 207) também confirma este entendimento nos seguintes termos: "Para que haja costume é mister a repetição habitual de um comportamento durante certo período de tempo. Consiste isso em seu elemento externo objetivo: inveterata longa consuetudo. Além disso, será preciso a consciência social da obrigatoriedade desse comportamento, a opinio juris necessitatis, que representa o seu elemento interno subjetivo".

2 A este respeito, confira-se as substanciosas lições de Marta Vinagre (1988, p. 119).

3 Nessa linha de raciocínio, de que o direito comercial/empresarial mantém tradicionalmente os usos e costumes como fontes subsidiárias, José Maria Rocha Filho e Gustavo Ribeiro Rocha (2015, p. 45) formulam a seguinte classificação: usos propriamente ditos ou usos de direito - os que são imperativos e têm força de lei, de sorte que a lei determina, no caso, a utilização do uso e costume do lugar. Assim, a eficácia desses usos e costumes decorreria da lei e não da vontade das partes; e os usos interpretativos ou convencionais - os que não são imperativos e recebem eficácia da simples vontade das partes. Decorrem estes, portanto, da prática espontânea dos comerciantes, ou seja, de sua utilização, a critério destes, em suas relações comerciais/empresariais.

Esta obra está bajo una Licencia Creative Commons

Atribución-NoComercial-SinDerivar 4.0 Internacional, IIJ-UNAM.

Boletín Mexicano de Derecho Comparado, núm. 151, pp. 227-262. 
A rigor, o reconhecimento dos usos e costumes comerciais constituiria verdadeiro princípio do direito comercial. Assim entendeu Marcelo Guedes Nunes em grupo de estudos preparatórios para o 1o. Congresso Brasileiro de Direito Comercial, ocorrido em 25 de março 2011 na Associação dos Advogados de São Paulo (AASP), do qual participaram renomados painelistas, tais como Calixto Salomão Filho, Erasmo Valladão, Fábio Ulhoa Coelho, Jairo Saddi e Nelson Eizirik.

Certo é que Marcelo Guedes (2011) refletiu sobre o tema e fez valiosas considerações. O jurista partiu da compreensão de que a dinâmica da atividade comercial faz com que os negócios entabulados com empresários se desenvolvam num ambiente de informalidade, sendo a atividade empresarial composta de sucessivos negócios interconexos de pequeno porte, pautados pela prática, rapidez e relacionamento de longo prazo, ou seja, por sucessivas e pequenas contratações. É neste contexto que surge a importância dos usos e costumes na regulação dos negócios empresariais, pois é sobre a prática costumeira e habitual que se assenta a credibilidade do tráfico negocial. É nos usos e costumes, pois, que fica registrado o padrão informal de trabalho do empresariado e é neles que encontramos o repositório de boas práticas para a regulação das relações empresariais. Para além disso, o dinamismo e a criatividade do empresariado tornam complexa a tarefa de julgar controvérsias apenas com base em regras gerais e abstratas previamente estabelecidas. Os usos e costumes, por se originarem de práticas que se disseminaram espontaneamente, poderiam então oferecer uma solução mais tendente à paz social e à acomodação de interesses conflitantes.

Na verdade, a importância dos usos e costumes não é novidade para o Direito. Há mais de meio século atrás, Rubens Requião (1959, p. 27) já ensinava que o direito comercial foi se desenvolvendo, emergido dos costumes e das decisões dos juízes consulares. Nessa linha, reconheceu o Superior Tribunal de Justiça que "o comércio, enquanto atividade marcada pelo dinamismo e celeridade, precede em muito o direito comercial, que tem marcante fonte consuetudinária, incorporando, desde suas origens medievais, as práticas comerciais dos mercadores associados em corporações de ofício" (STJ, EREsp. 1.024.691/PR, Rel. Min. Raul Araújo, 2a. Seção, DJe 29/12/2012).

Observe-se que, já na primeira fase do direito comercial, compreendia ele os usos e costumes mercantis observados na disciplina das relações 
jurídico-comerciais, sem nenhuma participação estatal. Cada corporação de ofício tinha seus próprios usos e costumes, e os aplicava, por meio de cônsules eleitos pelos próprios associados, para reger as relações entre os seus membros. Foi nesse período que algumas características próprias do direito comercial começaram a se delinear, como o informalismo e a influência dos usos e costumes no processo de elaboração de suas regras, como nos lembra André Luiz Santa Cruz Ramos (2006, p. 223). Em qualquer caso, é bem de ver que as inovações ocorridas no direito comercial estão intimamente ligadas às práticas do comércio e mais, que os usos e costumes das pessoas que fazem comércio têm sido, até hoje, uma importante fonte do Direito Comercial (Rohrmann, 2000).

De outra sorte, a repercussão dos usos e costumes estudados no direito comercial vai além do direito privado, alcançando também o direito público.

Fazendo uma pertinente incursão interdisciplinar, que favorece a compreensão do direito como ciência dotada de um tronco único, Claus Roxin (2007, p. 21), penalista alemão de escol, indica como desdobramento do princípio da legalidade a proibição de utilização do direito consuetudinário para fundamentação da pena. Segundo ele, "no Direito Penal, proíbe-se a fundamentação da punibilidade fora da lei escrita, no direito consuetudinário, ou seja, por meio de usos duradouros, sustentados pela convicção de sua obrigatoriedade”. Entretanto, Mario Losano (2007, p. 375), apoiado em Giuseppe Bettiol, ensina que não obstante essa reserva legal, o costume encontra aplicação também no direito penal, já que entre as descriminantes está o exercício regular de um direito, e um direito subjetivo pode fundamentar-se tanto em uma norma quanto em um costume, ou seja, um costume reconhecido pode gerar um direito subjetivo que, por sua vez, fundamenta uma descriminante favorável ao autor do fato. ${ }^{4}$

4 No mesmo sentido é a lição de Magalhães Noronha (1979, pp. 59-60), apoiada em Soler e Aníbal Bruno, segundo a qual não se pode negar valor ao direito consuetudinário. Isto porque, "primeiramente, tipos delituosos existem que invocam o costume, ao aludirem a certos elementos como honra, decoro, inexperiência, justificável confiança, mulher honesta etc. É impossível, então, o conhecimento da norma, desprezando-se o costume. Depois, há casos em que ele indiretamente é integrador do Direito Penal, quando a norma deste faz remissão a outra de diverso ramo jurídico, como o Civil ou o Comercial, que não o repudiam, e pode ser diretamente integrante quando, no mesmo caso, a norma civil, v. g., a ele se referir de modo direto, não obstante ser isso excepcional. Aceita igualmente é a sua influência, no tocante à extensão das causas excludentes da antijuridicidade ou da

Esta obra está bajo una Licencia Creative Commons

Atribución-NoComercial-SinDerivar 4.0 Internacional, IIJ-UNAM.

Boletín Mexicano de Derecho Comparado, núm. 151, pp. 227-262. 
Assim, por qualquer ângulo que se olhe, os costumes, oriundos que são de práticas sociais dotadas de continuidade, uniformidade, moralidade e conformidade com a lei, revelam importância e utilidade que não se limitam a um determinado ramo do direito, ou mesmo ao chamado direito privado, mas a todo o direito.

Conheçamos, agora, algo sobre o instituto dos usos e costumes no ordenamento nacional.

\section{USOS E COSTUMES NO DIREITO BRASILEIRO}

Após reconhecer a sua exígua atuação no direito civil brasileiro, limitada à disposição constante do artigo 4o. da LINDB (DL 4.657/1942), que consagra a sua aplicação no caso de falta ou omissão da lei ("Quando a lei for omissa, o juiz decidirá o caso de acordo com a analogia, os costumes e os princípios gerais de direito"), Washington de Barros Monteiro (1995, p. 18) esclarece que, no direito comercial, o costume abriu ensejo a mais amplas aplicações, tal como se observa no artigo 291 do revogado Código Comercial (Lei 556/1850), nos artigos 6o. a 8o. do Decreto 20.881/1931 (deu novo regulamento às Juntas dos Corretores de Mercadorias do Distrito Federal); no artigo 2o., letra "a", do Decreto 24.636/1934 (Regulamento do Departamento Nacional da Indústria e Comércio) e, ainda, nos artigos 8o., inc. VI e 35 da Lei 8.934/1994, ${ }^{5}$ ora regulamentada pelo Decreto 1.800, de 30 de janeiro de 1996, artigos 87 e $88 .{ }^{6}$

culpabilidade. Em muitos casos, o próprio fundamento da justificativa ou dirimente, ou a limitação de sua eficácia, está no costume, na prática uniforme e constante, segundo os interesses e tendências sociais e culturais".

5 O artigo 8o., VI da Lei 8.934/1994 estabelece que incumbe às Juntas Comerciais fazer o assentamento dos usos e práticas mercantis, ao passo que seu artigo 35, I veda o arquivamento dos documentos que não obedecerem às prescrições legais ou regulamentares ou que contiverem matéria contrária aos bons costumes ou à ordem pública. Porém, José Maria Rocha Filho (2015, pp. 44 e 45) destaca que a maneira mais correta de provar a existência e a vigência de um uso ou costume comercial consiste em obter da Junta Comercial da circunscrição territorial respectiva uma certidão nesse sentido, porque, nos termos do artigo 8o., VI da Lei 8.934, de 18/11/1994, cabe às Juntas Comerciais, com exclusividade, executar o assentamento ou o registro dos usos e práticas mercantis. E estão nos parágrafos do artigo 87 do Decreto 1.800/1996, que regulamentou aquela lei, as exigências para se fazer tal assentamento, de sorte que, inexistindo o registro, deverá o interessado fazer uso dos demais meios de prova admitidos em Direito. Alerta aquele autor que é perfeitamente possível inexista o registro, sobretudo nos dias atuais, tendo em vista 
A rigor, o Código Comercial de 1850 fez referência aos usos e costumes nos artigos 129, item 2 (estabelecia a nulidade dos contratos comerciais que recaíssem sobre objetos proibidos pela lei, ou cujo uso ou fim fos-

o avanço tecnológico e a rapidez com que se verificam as relações comerciais/empresariais. Exemplifica a lição, fazendo referência ao único uso e costume comercial que a Junta Comercial do Estado de Minas Gerais registrou desde a sua criação, ocorrida em 1893, relativo ao chamado "cheque visado", costume datado de 1965 e hoje em desuso, por conta dos cheques especiais e cartões magnéticos. Aliás, é também de 1965 o último assentamento realizado pela Junta Comercial do Estado de São Paulo, explica Márcio Catapani (2011, pp. 55 e 56) em seu excelente artigo, onde explica o "desuso" do assentamento em razão do grande incremento na edição de atos normativos, especialmente de cunho econômico, por órgãos da Administração Pública, de modo que, em virtude da crescente intervenção do Estado sobre a economia, como agente normativo, os órgãos da Administração Pública tomaram para si a tarefa de regular as minúcias das relações econômicas privadas. E, nesse contexto, os costumes porventura criados (ou em criação) foram percebidos e assimilados pelo ente normatizador, sendo incorporados nas normas por ele baixadas. Com isso, não teria sentido a Junta reproduzir o que já consta das normas editadas por outros órgãos, mesmo porque o Poder Executivo passou a influenciar, inclusive, o mecanismo de "seleção natural" dos costumes, interferindo em sua formação. Some-se a isto a falta de utilização dos assentamentos, ao menos expressamente, pelo Poder Judiciário que, salvo raras exceções, não faz referência aos costumes nas decisões judiciais, o que faz com que os assentamentos percam boa parte de sua valia. Por fim, a autorregulação observada em determinados setores, como o atinente à bolsa de valores, também tornou desnecessário o assentamento dos costumes, na medida em que outras entidades, de caráter privado, passaram a exercer função semelhante.

6 Artigo 87. O assentamento de usos ou práticas mercantis é efetuado pela Junta Comercial.

$\S 1$ 1o. Os usos ou práticas mercantis devem ser devidamente coligidos e assentados em livro próprio, pela Junta Comercial, ex officio, por provocação da Procuradoria ou de entidade de classe interessada.

$\S 2$ o. Verificada, pela Procuradoria, a inexistência de disposição legal contrária ao uso ou prática mercantil a ser assentada, o Presidente da Junta Comercial solicitará o pronunciamento escrito das entidades diretamente interessadas, que deverão manifestar-se dentro do prazo de noventa dias, e fará publicar convite a todos os interessados para que se manifestem no mesmo prazo.

§ 3o. Executadas as diligências previstas no parágrafo anterior, a Junta Comercial decidirá se é verdadeiro e registrável o uso ou prática mercantil, em sessão a que compareçam, no mínimo, dois terços dos respectivos vogais, dependendo a respectiva aprovação do voto de, pelo menos, metade mais um dos Vogais presentes.

$\S 4$ o. Proferida a decisão, anotar-se-á o uso ou prática mercantil em livro especial, com a devida justificação, efetuando-se a respectiva publicação no órgão oficial da União, do Estado ou do Distrito Federal, conforme a sede da Junta Comercial.

Artigo 88. Quinquenalmente, as Juntas Comerciais processarão a revisão e publicação da coleção dos usos ou práticas mercantis assentados na forma do artigo anterior.

Esta obra está bajo una Licencia Creative Commons

Atribución-NoComercial-SinDerivar 4.0 Internacional, IIJ-UNAM.

Boletín Mexicano de Derecho Comparado, núm. 151, pp. 227-262. 
se manifestamente ofensivo à sã moral e bons costumes); 130 (estabelecia que as palavras constantes dos contratos e convenções mercantis deveriam ser entendidas segundo o costume e uso recebido no comércio, e pelo mesmo modo e sentido adotados pelos negociantes, para que não significassem coisa diversa); 131, item 4 (havendo necessidade de se interpretar as cláusulas do contrato, referida interpretação deveria se basear no uso e prática geralmente observados no comércio em casos de mesma natureza, especialmente o costume do lugar onde o contrato devesse ser executado, prevalecendo sobre qualquer outra compreensão a respeito); 154 (o comitente era obrigado a pagar ao mandatário todas as despesas e desembolsos que este fizesse na execução do mandato, bem como os salários ou comissões que fossem devidos por ajuste expresso, ou por uso e prática mercantil do lugar onde se cumprisse o mandato, na falta de ajuste); 169, item 2 (estabelecia que o comissário que se afastasse das instruções recebidas ou não satisfizesse, na execução do mandato, ao que fosse de estilo e uso do comércio, responderia por perdas e danos ao comitente, salvo se a medida não comportasse demora e agisse aquele de acordo com o costume geralmente praticado no comércio); 201 (sendo a venda feita com base em amostras, ou designando-se no contrato qualidade de mercadoria conhecida nos usos do comércio, não era lícito ao comprador recusar-se a recebê-la, se os gêneros correspondessem fielmente às amostras apresentadas ou à qualidade designada; havendo dúvida, seria a questão decidida por árbitros); 207, item 2 (corriam por conta do vendedor os danos que a coisa vendida sofresse antes de sua entrega, quando, por condição expressa no contrato, ou por uso praticado no comércio, o comprador tivesse o direito de a examinar e declarar se contenta com ela, antes que a venda fosse tida por perfeita e irrevogável); 234 (quanto à locação mercantil de coisa ou trabalho, uma vez concluída a obra na conformidade do ajuste, ou, não o havendo, na forma do costume geral, o que a encomendou seria obrigado a recebê-la; se, porém, a obra não tiver na forma do contrato, plano dado, ou costume geral, poderia enjeitá-la ou exigir que se fizesse o abatimento no preço); 291 (estabelecia que as leis particulares do comércio, a convenção das partes, sempre que lhes não fosse contrária, e os usos comerciais, regulariam toda a sorte de associação mercantil; não podendo recorrer-se ao direito civil para decisão de qualquer dúvida que se ofereça, senão na falta de lei ou uso comercial); 673, item 3 (quanto ao seguro marítimo, surgindo dúvida sobre a compreensão de alguma das condições 
ou cláusulas da apólice, a decisão seria determinada pelo costume geral, observado em casos idênticos na praça onde se celebrou o contrato, que prevaleceria sobre qualquer outra significação que as palavras pudessem ter em seu uso vulgar) e 742, item 1 (no que toca à "arribada forçada", quando então um navio entra, por necessidade, em algum porto ou lugar distinto do planejado em viagem, tinha-se-lhe por injustificada quando a falta de víveres ou de aguada decorresse de imprevidência em face do costume e uso da navegação), sendo oportuno esclarecer que estes dois últimos dispositivos do Código ainda estão em vigor. ${ }^{7}$

Em caráter complementar ao código, porém relevante, os usos e costumes tiveram disciplina também nos artigos 2o., 3o. e 216 a 222 (versavam sobre a prova dos usos comerciais e do costume em geral) do Regulamento 737 (norma processual) e, somente os usos (não os costumes), nos artigos 12 e 22 a 27 do Regulamento 738, que versava sobre os Tribunais do Comércio, ambos de 25 de novembro de 1850.

Já no Código Civil de 1916, os usos e costumes aparecem nos artigos 588, §2o. (tratava do direito de tapagem e conceituava "tapume", observadas as dimensões estabelecidas em posturas municipais, de acordo com os costumes de cada localidade); 1.192, inc. II (estabelecia a obrigação do locatório de pagar pontualmente o aluguel nos prazos ajustados e, na falta de ajuste, segundo o costume do lugar); 1.210 (dispunha que, não havendo estipulação em contrário, o tempo da locação de prédio urbano regularse-ia pelos usos locais); 1.215 (estabelecia que o locatário que entrasse em um prédio rústico deveria facilitar ao que sai o uso do que fosse necessário para que este fizesse a colheita, segundo o costume do lugar); 1.218 (em se tratando de locação de serviços, se não houvesse estipulação ou acordo entre as partes, fixar-se-ia por arbitramento a retribuição devida segundo o costume do lugar, tempo de serviço e qualidade deste); 1.219 (a retribuição mencionada seria paga depois de prestado o serviço se, por convenção ou costume, não tivesse de ser adiantada ou paga em prestações); 1.221 (previa que não havendo prazo estipulado, nem se podendo inferir da natureza do contrato, ou do costume do lugar, qualquer das partes a seu

7 Cumpre observa aqui, segundo convenientemente ressaltado por João Eunápio Borges (1964, p. 74), a linguagem do Código revogado para designar os usos comerciais variou em cada um dos dispositivos em que a eles se refere: "no artigo 154, fala em 'uso e prática mercantil'; no artigo 169, em 'estilo e uso do comércio'; no artigo 179, em 'estilo da Praça'; no art. 186, em 'uso comercial'; no art. 201, em 'usos do comércio'; no art. 207, n 2 , em 'uso praticado em comércio', e no art. 291, em 'usos comerciais".

Esta obra está bajo una Licencia Creative Commons

Atribución-NoComercial-SinDerivar 4.0 Internacional, IIJ-UNAM.

Boletín Mexicano de Derecho Comparado, núm. 151, pp. 227-262. 
arbítrio, mediante prévio aviso, poderia rescindir o contrato) e 1.242 (no que tange à empreitada, uma vez concluída a obra de acordo com o ajuste ou o costume do lugar, o dono ficaria obrigado a recebê-la, só podendo enjeitá-la se o empreiteiro se afastasse das instruções recebidas e dos planos dados, ou das regras técnicas inerentes ao trabalho). ${ }^{8}$

Quanto à lei adjetiva, usos e costumes encontraram regramento nos artigos 259 a 262 em nosso Código de Processo Civil de 1939, o Decretolei n ${ }^{\circ} 1.608 / 1939$, quando então podiam ser provados pelos meios admitidos em juízo. Os usos e costumes de natureza comercial, quando de praça nacional, poderiam ser provados por certidão das repartições incumbidas do respectivo registro; quando estrangeiros, seriam provados por ato autêntico, devidamente legalizado, do país de origem. Em qualquer caso, o juízo que julgasse provado o uso ou costume comercial remeteria cópia da decisão à repartição competente para que a mesma fosse registrada e arquivada..$^{9}$

A Lei de Introdução ao Código Civil, que hoje se chama Lei de Introdução às Normas do Direito Brasileiro, além do que foi estabelecido em seu artigo 4o., também se refere aos costumes em seu artigo 17, ao dispor que "as leis, atos e sentenças de outro país, bem como quaisquer declarações de vontade, não terão eficácia no Brasil, quando ofenderem a soberania nacional, a ordem pública e os bons costumes". ${ }^{10}$

8 De acordo com Dirceu de Mello (2007, p. 82), "basta a consulta ao texto de 1916, propriamente, para que se observe que o legislador civil, a cada passo, prestigiou e elevou o costume à condição de fonte imediata do direito (arts. 588, $\S 2^{\circ}, 1.192,1.210,1.215,1.218$ e 1.219, por exemplo). Até que, com o Decreto-lei n ${ }^{\circ} 4657$, de 4 de setembro de 1942 , mereceu a questão o tratamento que se tem como adequado". Posteriormente, elucida o autor, "o Código Civil de 2002 ratificou a importância do costume como fonte imediata do direito, reproduzindo alguns dos dispositivos do texto de 1916 (artigos 569, 596, 597 e 1.297 , § lo., por exemplo)".

9 Além desses dispositivos, cumpre observar, o artigo 212 do diploma em questão estabelecia que aquele que alegasse direito estadual, municipal, costumeiro, singular ou estrangeiro, deveria provar-lhe o teor e a vigência, salvo se o juiz dispensasse a prova. Já o artigo 461 fazia menção à afixação de editais "no lugar de costume", ou seja, no lugar de praxe. Por fim, o artigo 792, que tinha por objeto a homologação de sentenças estrangeiras, pontuava que, não obstante satisfeitos os requisitos do artigo 791, as sentenças não seriam homologadas, se contivessem decisão contrária à soberania nacional, à ordem pública ou aos bons costumes (destaque nosso).

10 Com apoio em Clóvis Beviláqua e Oscar Tenório, Maria Helena Diniz (2010, p. 6) se refere ao costume de que trata o artigo 4o. como meio de preenchimento de lacunas no direito, ao passo que aqueles mencionados no artigo 17 da LICC, os bons costumes, 
Os costumes são mencionados no Código de Processo Civil de 1973 (Lei 5.869/1973) apenas nos artigos 126 (dispõe que o juiz não se exime de sentenciar ou despachar alegando lacuna ou obscuridade da lei, de sorte que, no julgamento da lide, caber-lhe-á aplicar as normas legais e, não as havendo, recorrerá à analogia, aos costumes ${ }^{11}$ e aos princípios gerais de direito); ${ }^{12} 337$ (dispõe que a parte que alegar direito municipal, estadual, estrangeiro ou consuetudinário, provar-lhe-á o teor e a vigência, ${ }^{13}$ se as-

seriam normas de proceder nas relações domésticas e sociais que estivessem em harmonia com os elevados fins da vida humana. Abrangeriam, assim, valores morais tutelados direta ou indiretamente pelo direito.

11 Ao comentar o dispositivo sob exame, Nelson Nery Júnior (1994, p. 383) explica que as regras costumeiras também podem ser aplicadas na solução do litígio, atuando, então, praeter legem; mas não devem ser aplicadas se contrariarem (contra legem) o sistema positivo. Considerando a predominância da norma escrita no direito brasileiro, afirma o autor que as regras costumeiras caíram em desuso, sendo praticamente destituídas de objeto.

12 Complementando a lição, Cândido Rangel Dinamarco (2013, p. 91) ensina que "a integração da norma processual consiste em suprir lacunas da lei mediante o recurso aos princípios gerais de direito, aos usos-e-costumes (que são fonte do direito) e à analogia".

13 A este respeito, Nelson Nery Júnior (1994, p. 521) esclarece que a prova do costume que inspirou o ato ou o negócio jurídico deve ser feita por quem o eleja, ilustrando a lição com um julgado datado de 20 de maio de 1941 (RT 132/660/2), que envolveu uma negociação de gado no mercado de Barretos - SP, onde, por mais alto fosse o valor do ajuste, seria celebrado na base da confiança e sem documento escrito. Destaque-se, entretanto, que excepcionalmente a prova do costume pode ser feita por meio de testemunhas. Foi o entendimento do Superior Tribunal de Justiça ao apreciar o REsp 877.074 - RJ (2006/0175650-4), que teve um voto emblemático, rica lição aos operadores do direito, cuja leitura se recomenda, restando assim ementado: "Comercial. Recurso especial. Ação de cobrança. Prestação de serviço de transporte rodoviário. Cargas agrícolas destinadas a embarque em porto marítimo. Cobrança originada por atraso no desembaraço das mercadorias no destino. Discussão a respeito da responsabilidade do contratante pelo pagamento das sobrestadias. Requerimento de produção de prova testemunhal para demonstração de costume comercial relativo à distribuição de tal responsabilidade. Natureza dos usos e costumes mercantis. Sistema de registro dos costumes por assentamento nas Juntas Comerciais. Costume contra legem. Conflito entre duas fontes subsidiárias de direito comercial (Lei civil e costume comercial) no contexto relativo à vigência do Código Comercial de 1850 e do Código Civil de 1916. - Atualmente, a Lei n ${ }^{\circ}$ 8.934/94 atribui competência às Juntas Comerciais para proceder ao assentamento dos usos e práticas mercantis. Impertinente, portanto, a alegação da recorrente no sentido de que nenhum regulamento portuário indica ser de responsabilidade da contratante do serviço de transporte o pagamento das eventuais sobrestadias, pois não cabe a tais regulamentos consolidar usos e costumes mercantis relativos ao transporte terrestre de bens. - Há desvio de perspectiva na afirmação de que só a prova documental derivada do assentamento demonstra um uso ou costume comercial. O que ocorre é a atribuição de um valor especial - de prova plena - àquela assim

Esta obra está bajo una Licencia Creative Commons

Atribución-NoComercial-SinDerivar 4.0 Internacional, IIJ-UNAM.

Boletín Mexicano de Derecho Comparado, núm. 151, pp. 227-262. 
sim o determinar o juiz); 405, § 3o., inc. II (considera suspeito e, pois, não passível de depor como testemunha quem, por seus costumes - comportamento - não for digno de fé) e, por fim, no artigo 687, de onde se extrai que o edital será afixado no local do costume (de praxe, usual) e publicado, em resumo, com antecedência mínima de cinco dias, pelo menos uma vez em jornal de ampla circulação local.

A bem da verdade, os artigos 337 e 687 supracitados encontram identidade ou semelhança nos artigos 376 e 887, §3o., do Novo Código de Processo Civil (Lei 13.105/2015) que, aparentemente, é o estatuto processual mais pobre que o Brasil já teve no trato e valorização dos costumes.

No que pertine ao Código Civil em vigor (Lei 10.406/2002), os costumes estão presentes nos artigos 13 (proíbe o ato de disposição do próprio corpo quando isto contrariar os bons costumes); 111 (o silêncio importa anuência, quando as circunstâncias ou os usos o autorizarem, e não for necessária a declaração de vontade expressa), ${ }^{14} 113$ (os negócios jurídi trá-

constituída; mas disso não se extrai, como pretende a recorrente, que o assentamento é o único meio de se provar um costume. - Não é possível excluir, de plano, a possibilidade de que a existência de um costume mercantil seja demonstrada por via testemunhal. - Da simples autorização para produção de prova testemunhal não decorre, automaticamente, qualquer imputação de responsabilidade a uma das partes. Trata-se apenas de, uma vez demonstrada a existência do costume, tomá-lo como regra jurídica para a solução do litígio. Tal solução, porém, dependerá ainda da verificação da subsunção do suporte fático àquele comando, em atividade cognitiva posterior. - A adoção de costume contra legem é controvertida na doutrina, pois depende de um juízo a respeito da natureza da norma aparentemente violada como sendo ou não de ordem pública. - Na hipótese, não se trata apenas de verificar a imperatividade ou não do dispositivo legislado, mas também analisar o suposto conflito entre duas fontes subsidiárias do Direito Comercial - quais sejam, a lei civil e o costume mercantil, levando-se em conta, ainda, que a norma civil apontada como violada — qual seja, o artigo 159 do CG/16 - não regula, de forma próxima, qualquer relação negocial, mas apenas repete princípio jurídico imemorial que remonta ao neminem laedere romano. - Especialmente em um contexto relativo ao período em que não havia, ainda, ocorrido a unificação do direito privado pelo CG/02, é impossível abordar o tema de forma lacônica, como se fosse possível afirmar, peremptoriamente e sem maiores aprimoramentos, a invalidade apriorística de todo e qualquer costume comercial em face de qualquer dispositivo da Lei civil, ainda que remotamente aplicável à controvérsia. Recurso especial parcialmente conhecido e, nessa parte, não provido" (STJ, REsp 877.074/RJ, Rel. Min. Nancy Andrighi, 3a. Turma, julgado em 12/05/2009, DJe 17/08/2009).

14 Como visto linhas atrás, as referências mais abrangentes que temos sobre os usos e costumes no Código Civil em vigor estão nos artigos 111 e 113 . Em relação ao primeiro dispositivo (artigo 111), Carlos Roberto Gonçalves (2012, p. 335) esclarece que "normalmente, o silêncio nada significa, por constituir total ausência de manifestação de vontade e, 
cos devem ser interpretados conforme a boa-fé e os usos do lugar de sua celebração), ${ }^{15} 122$ (consagra a regra geral da licitude das condições não con-

como tal, não produzir efeitos. Todavia, excepcionalmente, em determinadas circunstâncias, pode ter um significado relevante e produzir efeitos jurídicos. [...] Portanto, o silêncio pode ser interpretado como manifestação tácita da vontade quando a lei conferir a ele tal efeito... O silêncio pode ser igualmente interpretado como consentimento quando tal efeito ficar convencionado em um pré-contrato ou ainda resultar dos usos e costumes, como se infere do artigo 432 do Código Civil". Conclui o autor afirmando que "cabe ao juiz examinar caso por caso, para verificar se o silêncio, na hipótese sub judice, traduz, ou não, vontade". Foi o que fez o Superior Tribunal de Justiça ao decidir: "DIREITO GIVIL. DIREIto dos contratos. Seguro. Contrato consensual. Momento em Que é ConsiDERADO PERFEITO E ACABADO. MANIFESTAÇÃO DE VONTADE, AINDA QUE TÁCITA. CONTRATAÇÃO JUNTO À CORRETORA. PREENCHIMENTO DA PROPOSTA COM AUTORIZAÇÃO DE PAGAMENTO DO PRÊMIO POR DÉBITO EM CONTA. SINISTRO. OCORRÊNCIA ANTES DA EMISSÃO DA APÓLICE. NEGATIVA DE COBERTURA. DESCABIMENTO. 1. O seguro é contrato consensual e aperfeiçoa-se tão logo haja manifestação de vontade, independentemente de emissão da apólice - ato unilateral da seguradora -, de sorte que a existência da avença não pode ficar à mercê exclusivamente da vontade de um dos contratantes, sob pena de ter-se uma conduta puramente potestativa, o que é, às expressas, vedado pelo artigo 122 do Código Civil. 2. O artigo 758 do Código Civil não confere à emissão da apólice a condição de requisito de existência do contrato de seguro, tampouco eleva tal documento ao degrau de prova tarifada ou única capaz de atestar a celebração da avença. 3. É fato notório que o contrato de seguro é celebrado, na prática, entre a corretora e o segurado, de modo que a seguradora não manifesta expressamente sua aceitação quanto à proposta, apenas a recusa ou emite, diretamente, a apólice do seguro, enviando-a ao contratante, juntamente com as chamadas condições gerais do seguro. Bem a propósito dessa praxe, a própria Susep disciplinou que a ausência de manifestação por parte da seguradora, no prazo de 15 (quinze) dias, configura aceitação tácita da cobertura do risco, conforme dispõe o artigo 2o., caput e § 6o., da Circular Susep n. 251/2004. 4. Com efeito, havendo essa prática no mercado de seguro, a qual, inclusive, recebeu disciplina normativa pelo órgão regulador do setor, há de ser aplicado o artigo 432 do Código Civil, segundo o qual '[s]e o negócio for daqueles em que não seja costume a aceitação expressa, ou o proponente a tiver dispensado, reputar-se-á concluído o contrato, não chegando a tempo a recusa'. Na mesma linha, o artigo 111 do Estatuto Civil preceitua que '[o] silêncio importa anuência, quando as circunstâncias ou os usos o autorizarem, e não for necessária a declaração de vontade expressa'. Doutrina e precedente. 5. No caso, não havendo nenhuma indicação de fraude e tendo o sinistro ocorrido efetivamente após a contratação junto à corretora de seguros, ocasião em que o consumidor firmou autorização de pagamento do prêmio mediante débito em conta, se em um prazo razoável não houve recusa da seguradora, só tendo havido muito tempo depois e exclusivamente em razão do sinistro noticiado, há de considerar-se aceita a proposta e plenamente aperfeiçoado o contrato. Deveras, vulnera os deveres de boa-fé contratual a inércia da seguradora em aceitar expressamente a contratação, vindo a recusá-la somente depois da notícia de ocorrência do sinistro e exclusivamente em razão disso. 6. Recurso especial não provido (STJ, REsp 1306367 /SP, Rel. Min. Luís Felipe Salomão, 4a. Turma,

Esta obra está bajo una Licencia Creative Commons

Atribución-NoComercial-SinDerivar 4.0 Internacional, IIJ-UNAM.

Boletín Mexicano de Derecho Comparado, núm. 151, pp. 227-262. 
rias à lei, à ordem pública ou aos bons costumes); 187 (caracteriza como ilícito o excesso no exercício de um direito quando isto extrapolar os limites impostos também pelos bons costumes); 1.297, § 1o. (estabelece, em relação aos limites entre prédios e ao direito de tapagem, que os intervalos, muros, cercas e tapumes divisórios presumem-se pertencer a ambos os proprietários confinantes, que ficam obrigados, de acordo com os costumes da localidade, a concorrer, em partes iguais, para as despesas de sua construção e conservação); 1.336, inc. IV (estabelece como dever do condômino dar às suas partes a mesma destinação que tem a edificação, e não as utilizar de maneira prejudicial ao sossego, salubridade e segurança dos possuidores, ou aos bons costumes); 1.638, inc. III (a prática de atos

julgado em 20/03/2014, DJe 05/05/2014), destaque nosso. No voto respectivo, onde se depara com situação em que o segurado teve seu veículo furtado treze dias após firmar o contrato de seguro, mas antes mesmo da emissão da apólice, extrai-se o seguinte trecho, interessante ao presente estudo: "Nesse ponto, em comentários aos citados dispositivos legais, a doutrina confirma o valor dos costumes na formação do contrato: Em regra, a aceitação do agente se manifestará de forma expressa. Seja pessoalmente, seja por outras vias acrescidas pela sociedade moderna, avulta o consenso, dispensando-se formalidades. ...Muitas vezes, contudo, os costumes e convenções sociais indicam condutas e gestos que evidenciam aceitação, como o acenar com um movimento de braço em um lance de leilão. Cuida-se de aceitação implícita baseada em padrões sociais... Ademais, podem-se convencionar formas alternativas de aceitação em cláusula contratual. Basta pensar em um contrato de empreitada em que o negócio jurídico será renovado em caso de ausência de manifestação das partes em determinado prazo previamente assinalado. A segunda parte do artigo [432] se refere a casos em que o proponente dispensa a aceitação expressa pelo oblato. Assim, se é dado um prazo de trinta dias, superado o termo, a aceitação se presume pela conduta passiva do aceitante. Recorde-se que, em princípio, o silêncio não autoriza a emissão da vontade negocial. Porém, o artigo 111 do CG infere a manifestação de vontade extraída do silêncio, quando as circunstâncias e os usos autorizarem. Ou seja, há casos em que o silêncio revela um comportamento concludente e possui significado social relevante, produzindo efeitos positivos (Peluso, Cezar (coord.). Código Civil comentado. 6a. ed., Barueri/SP: Manole, 2012, pp. 500 ne 501)", destaque nosso.

15 Já em relação a este dispositivo legal (artigo 113), Gustavo Tepedino e Anderson Schreiber (2003, p. 144-145) ensinam que a doutrina brasileira atribui à boa-fé uma tríplice função, assim composta: (a) função interpretativa dos contratos (artigo 113); (b) função restritiva do exercício abusivo de direitos contratuais (artigo 187); e (c) função criadora de deveres anexos ou acessórios à prestação principal, tais como o dever de informação e o dever de lealdade (artigo 422). Na primeira função, "alude-se à boa-fé como critério hermenêutico, exigindo que a interpretação das cláusulas contratuais privilegie sempre o sentido mais conforme à lealdade e à honestidade entre as partes. Proíbe-se, assim, a interpretação que dê a uma disposição contratual um sentido malicioso ou de qualquer forma dirigido a iludir ou prejudicar uma das partes, em benefício da outra". 
contrários à moral e aos bons costumes leva à perda, por ato judicial, do poder familiar, por qualquer dos pais) e 1.735, inc. IV (torna incompatíveis com a tutela as pessoas condenadas por crimes contra os costumes, dentre outros bens jurídicos) do Código Civil em vigor.

Usos e costumes estão presentes, ainda, no Projeto do Novo Código Comercial, o PL 1.572/2011, em seus artigos 303 (eleva o reconhecimento dos usos e costumes do comércio à condição de princípio do direito contratual empresarial); 308 (considera válidas e eficazes as cláusulas do contrato empresarial em que as partes contraem obrigações de acordo com os usos e costumes do comércio, internacional ou local); 318 , inc. V (estabelece que o contrato empresarial deve ser interpretado de modo a considerar que os usos e costumes praticados no segmento da atividade econômica relativa ao objeto daquele ajuste sirvam de critério para interpretação das cláusulas contratadas, prevalecendo sobre os demais), 319 (dispõe que, no caso de omissão do contrato, presume-se que as partes acordaram em se submeter aos usos e costumes praticados no lugar da execução do mesmo) e 511, § 2o. (dispõe que a determinação do valor da moeda estrangeira, no caso de o pagamento ter sido estipulado em moeda sem curso legal no lugar do pagamento, será feita segundo os usos deste mesmo lugar).

Assim, como se vê, o instituto dos usos e costumes sempre esteve presente em nosso ordenamento, ora com mais força, como no passado, ora com menos intensidade, mostrando-se respeitável a intenção porventura manifestada em um novo e eventual diploma comercial no sentido de promover a revalorização dos usos e costumes, como forma de aperfeiçoar contratos e negócios. ${ }^{16}$

\section{USOS E COSTUMES EM ALGUNS DIPLOMAS ESTRANGEIROS}

No presente tópico, analisar-se-á brevemente algumas disposições normativas envolvendo as figuras dos usos e costumes em outros ordenamentos mais próximos ao brasileiro.

16 Afinal, como bem observou Daniel Queiroga (2015, p. 86), “os contratos são de fundamental importância para a vida da sociedade empresária ou do empresário, pois são os responsáveis pela necessária circulação de bens e serviços imprescindíveis para a atividade econômica organizada profissionalmente na busca do lucro e a acumulação de riquezas, baseada na autonomia da vontade, na boa-fé e na assunção do risco”.

Esta obra está bajo una Licencia Creative Commons

Atribución-NoComercial-SinDerivar 4.0 Internacional, IIJ-UNAM.

Boletín Mexicano de Derecho Comparado, núm. 151, pp. 227-262. 
Nesse sentido, oportuno mencionar o Código de Comércio da Espanha, o Real Decreto datado de 22 de agosto de 1885 e recentemente alterado em 2014, onde os usos estão presentes nos artigos 2o. (os usos do comércio regerão os atos de comércio subsidiariamente ao Código) e 304 (versa sobre o contrato de depósito), enquanto que os costumes encontraram abrigo no artigo 261 (cuida do contrato de comissão mercantil).

Já o velho Código de Comércio da Argentina, Lei 2.637, de 5 de outubro de 1889, tratava dos usos nos artigos 187 (que cuidava dos transportadores, carregadores ou empresários de transporte), 216 (que dizia respeito aos contratos e obrigações em geral) e 456 (que tratava da compra e venda mercantil), fazendo menção aos costumes não só em seu importante Título Preliminar, ${ }^{17}$ mas também nos artigos 146 (reconhecia validade ao contrato firmado pelo gerente de um estabelecimento, mas não pelos meros auxiliares de comércio), 218 (trazia premissas relevantes para se fazer a interpretação de cláusulas contratuais) e 242 (cuidava do comissionista e das hipóteses capazes de justificar o excesso na execução do contrato), com destaque para o "Anexo A" do referido Código, que por assim dizer reproduz aquele mesmo Título Preliminar. Ao que parece, contudo, foi revogado pelo artigo 4o. do Código Civily Comercial de La Nación, Lei 26.994, del 7 de outubro de $2014 .^{18}$

\section{Título preliminar}

1. En los casos que no estén especialmente regidos por este Código, se aplicarán las disposiciones del Código Civil.

2. En las materias en que las convenciones particulares pueden derogar la ley, la naturaleza de los actos autoriza al juez a indagar si es de la esencia del acto referirse a la costumbre, para dar a los contratos y a los hechos el efecto que deben tener, según la voluntad presunta de las partes.

3. Se prohíbe a los jueces expedir disposiciones generales o reglamentarias, debiendo limitarse siempre al caso especial de que conocen.

4. Sólo al Poder Legislativo compete interpretar la ley de modo que obligue a todos. Esta interpretación tendrá efecto desde la fecha de la ley interpretada; pero no podrá aplicarse a los casos ya definitivamente concluidos.

5. Las costumbres mercantiles pueden servir de regla para determinar el sentido de las palabras of frases técnicas del comercio, y para interpretar los actos o convenciones mercantiles.

18 Neste recente diploma, já impresso e reimpresso em sua segunda edição (Argentina, 2016, p. XLI), o instituto dos usos e costumes aparece às páginas $5,45,50,58,67,128$, 133, 148, 158, 159, 160, 163, 170, 171, 175, 182, 183, 184, 185, 186, 189, 200, 201, 204, 206, 209, 216, 218, 219, 224, 233, 239, 242, 279, 280, 316, 317, 323, 327, 337, 407, 408, cujo exame, evidentemente, extrapolaria o âmbito do presente estudo. 
Interessante também é o Código de Comércio Mexicano de 1889, reformado em $2017,{ }^{19}$ no qual o instituto dos usos está presente nos artigos 6 bis (impõe aos comerciantes o dever de realizar sua atividade de acordo com os usos honestos em matéria industrial ou comercial), 333 (os usos da praça em que se constituiu o depósito podem ser utilizados para fixar a remuneração do depositário) e 1445 (em todos as hipóteses mencionadas no dispositivo, o tribunal arbitral decidirá de acordo com as estipulações do que foi convencionado e levará em consideração os usos mercantis aplicáveis ao caso). Já a menção aos costumes é feita nos artigos 280 (o comissário poderá empregar, sob sua responsabilidade, no desempenho do mandato, subordinados para realizarem operações secundárias que, segundo o costume, se confiem a estes); 590, inc. III (no que diz respeito ao contrato mercantil de transporte terrestre, o transportador está obrigado a realizar a viagem desde logo, se não houver termo ajustado; e o mais próximo da data do contrato, se habituado a fazê-las periodicamente); 1.068, inc. IV (as notificações em procedimento judicial também podem ser feitas por editais fixados de forma ostensiva nos lugares públicos de costume) e 1.132, inc. IV (trata do impedimento judicial decorrente de relações íntimas entre o juiz e a parte interessada, em virtude de ato religioso ou civil chancelado pelo costume).

Entretanto, especialmente importante parece o Código de Comércio da Colômbia, (Decreto 410/1971), que dedicou aos usos quatros dispositivos, a saber, os artigos 640 (que trata da emissão de títulos por mandatários ou representantes), 1.524 (versa sobre o que não se considera avaria comum em direito marítimo); 1.697 (cuida da compra e venda marítima que compreenda custo, seguro e frete) e 1.698 (dispõe sobre a compra e venda marítima que compreenda custo e frete), dedicando também muitos artigos à valorização dos costumes.

Embora a essência do regramento esteja nos artigos 3o. a 9o. do Código, cuja leitura se recomenda, ${ }^{20}$ os costumes aparecem também, de uma forma ou de outra, nos artigos 86 (funções das câmaras de comércio), 96

19 La adición al libro quinto del título especial bis denominado "Del juicio ejecutivo mercantil oral", con los artículos 1390 ter al 1390 ter 15, publicada en el DOF 25-01-2017, entrará en vigor el 25 de enero de 2018.

20 Artigo 30. Validez de la Costumbre Mercantil. La costumbre mercantil tendrá la misma autoridad que la ley comercial, siempre que no la contraríe manifiesta o tácitamente y que los hechos constitutivos de la misma sean públicos, uniformes y reiterados en el lugar

Esta obra está bajo una Licencia Creative Commons

Atribución-NoComercial-SinDerivar 4.0 Internacional, IIJ-UNAM.

Boletín Mexicano de Derecho Comparado, núm. 151, pp. 227-262. 
(funções da confederação de câmaras de comércio), 606 (na disciplina das denominações que não podem ser utilizadas como nome empresarial), 827 (na assinatura ou firma por meio mecânico), 842 (na representação aparente), 871 (no trato do princípio da boa-fé), 909 (no regramento dos gastos relativos ao contrato de compra e venda), 911 e 912 (versam sobre a coisa que é ou pode ser vendida por "amostra”), 923 (nas modalidades de entrega da coisa), 933 (na presunção de venda com garantia), 935 (no ônus da prova em contrato de compra e venda), 969 (nas regras para estabelecer a quantidade do fornecimento), 971 (no pagamento do preço no contrato

donde hayan de cumplirse las prestaciones o surgido las relaciones que deban regularse por ella.

En defecto de costumbre local se tendrá en cuenta la general del país, siempre que reúna los requisitos exigidos en el inciso anterior.

Artigo 40. Preferencia de las estipulaciones contractuales. Las estipulaciones de los contratos válidamente celebrados preferirán a las normas legales supletivas y a las costumbres mercantiles.

Artigo 50. Aplicación de la costumbre mercantil. Las costumbres mercantiles servirán, además, para determinar el sentido de las palabras o frases técnicas del comercio y para interpretar los actos y convenios mercantiles.

Artigo 6o. Prueba de la costumbre mercantil. La costumbre mercantil se probará como lo dispone el Código de Procedimiento Civil. Sin embargo, cuando se pretenda probar con testigos, éstos deberán ser, por lo menos, cinco comerciantes idóneos inscritos en el registro mercantil, que den cuenta razonada de los hechos y de los requisitos exigidos a los mismos en el artículo 3o.; y cuando se aduzcan como prueba dos decisiones judiciales definitivas, se requerirá que éstas hayan sido proferidas dentro de los cinco años anteriores al diferendo.

Artigo 7o. Aplicación de tratados, convenciones y costumbre internacionales. Los tratados o convenciones internacionales de comercio no ratificados por Colombia, la costumbre mercantil internacional que reúna las condiciones del artículo 3o., así como los principios generales del derecho comercial, podrán aplicarse a las cuestiones mercantiles que no puedan resolverse conforme a las reglas precedentes.

Artigo 80. Prueba de la costumbre mercantil extranjera. Acreditación. La prueba de la existencia de una costumbre mercantil extranjera, y de su vigencia, se acreditará por certificación del respectivo cónsul colombiano o, en su defecto, del de una nación amiga. Dichos funcionarios para expedir el certificado solicitarán constancia a la cámara de comercio local o de la entidad que hiciere sus veces y, a falta de una y otra, a dos abogados del lugar, de reconocida honorabilidad, especialistas en derecho comercial.

Artigo 90. Prueba de la costumbre mercantil internacional. Acreditación. La costumbre mercantil internacional y su vigencia se probarán mediante copia auténtica, conforme al Código de Procedimiento Civil, de la sentencia o laudo en que una autoridad jurisdiccional internacional la hubiere reconocido, interpretado o aplicado. También se probará con certificación autenticada de una entidad internacional idónea, que diere fe de la existencia de la respectiva costumbre. 
de fornecimento), 977 (no fim do contrato de fornecimento), 987 (no transporte multimodal, aquele que é feito por mais de um meio de transporte), 1.002 (na desistência do passageiro no contrato de transporte de pessoas), 1.016 (na redução ou diminuição natural da coisa transportada), 1.030 (na responsabilidade do transportador), 1.050 (na apólice flutuante e automática de seguro), 1.170 (na remuneração do contrato de depósito), 1.172 (nas proibições ao depositário), 1.180 (nos depósitos em armazéns gerais), 1.217 (na obrigatoriedade da inspeção, pelo credor, em caso de penhor sem posse deste), 1.249 (no encerramento da conta corrente e liquidação do saldo respectivo), 1.267 (na conduta do mandatário em casos não previstos pelo mandante), 1.291 (no desempenho pessoal e na delegação do contrato de comissão), 1.377 (no contrato de consignação ou estimatório), 1.417 (na responsabilidade e deveres dos bancos em relação ao que foi guardado em seus cofres), 1.501 (nas funções e obrigações dos capitães dos navios), 1.502 (nas proibições ao capitão), 1.513 (na definição de acidente ou sinistro marítimo), 1.538 (na indenização dos danos que uma embarcação cause a outra), 1.621 (na retirada da coisa transportada durante a viagem), 1.655 (na entrega e recebimento de coisas), 1.657 (no término da estadia de uma embarcação no porto), 1.658 (na contagem dos dias desta estadia), 1.659 (no término da sobrestadia dos navios), 1.661 (na compensação em razão de sobrestadia), 1.663 (no vencimento do prazo de sobrestadia para carregamento do navio), 1.666 (na definição do contrato de fretamento marítimo), 1.672 (no pagamento do frete), 1.688 (na obrigação do vendedor no caso de desembarque de coisa objeto de compra e venda marítima), 1.691 (na indicação do navio em caso de compra e venda marítima), 1.702 (no pagamento do preço por meio de um banco), 1.725 (na alteração da rota estipulada para o navio), 1.727 (no caso de se ter vários portos para desembarque da mercadoria) e 2.031 (na decisão do juiz em caso de divergência entre os peritos).

A esta altura, curioso observar que, a despeito das peculiaridades de cada país e cultura, determinados institutos jurídicos estão presentes nos diversos ordenamentos, a exemplo do que se verifica em algumas espécies de contratos comerciais (depósito, transporte, comissão mercantil, etc.) e do direito marítimo, ${ }^{21}$ recebendo, não raras vezes, regramento se-

21 A propósito do tema, Osvaldo Agripino de Castro Júnior (2010, p. 222) ensina que o direito marítimo "é disciplina de direito privado que tem como objeto regular as relações jurídicas em torno do navio, como contrato de transporte, contrato de afretamento 
melhante, seja por tradição histórica, necessidade premente de disciplina jurídica, deficiência institucional, dependência cultural ou simplesmente por se tomar a mesma fonte de inspiração para o direito legislado, replicando-o. Em qualquer caso, não é difícil perceber como o termo costume pode se revelar polissêmico para o direito.

Notável, ainda, que embora a necessidade de fortalecimento do comércio seja problema comum a todos os países em desenvolvimento, o velho e o novo direito comercial se apresentem como alternativas válidas para alcançar-se o desejado avanço social e econômico.

\section{SERIA POSSÍVEL VOLTARMOS AO VELHO GORAÇÃO DO DIREITO COMERCIAL?}

Para responder a esta indagação, é preciso compreendamos o que quis dizer Efraín Richard ao pregar a necessidade de voltarmos ao velho coração do direito comercial. Segundo aquele jurista, seria preciso

Voltar àquilo que nós chamamos de "velho coração do direito comercial", sempre renovado, num duplo esforço: um direito substancial mais simples, configurando o que chamamos de economia do direito, com menos normas mas mais efetivas, deixando as condutas à autonomia da vontade enquanto não infrinjam a ordem social pretendida, e, quando se mostrem desvios ou a necessidade de regulação, dispor de técnicas normativas mais que perfeitas. Ao mesmo tempo, uma justiça imediata, ou pelo menos mais eficiente... (Richard apud Féres, 2008, pp. 117-119).22

e responsabilidade civil, e que tem como fontes as convenções internacionais, o Código Civil, o Código Comercial e a Lex Maritima". Esclarece, ainda, que "o Direito Marítimo não se confunde com o Direito da Navegação Marítima, Direito do Mar e Direito Portuário, que possuem como objeto, regular, respectivamente, as relações jurídicas que se dão em torno da segurança da navegação e da proteção do meio ambiente marinho (DNM), o mar, tal como a plataforma continental (DM) e o porto (DP)". O mesmo autor (ibidem, p. 214) destaca que, no Brasil, as fontes do direito marítimo (quase $100 \%$ dependente das frotas de bandeiras estrangeiras) são operadas e aplicadas de forma automática e acrítica pelos operados de direito, sendo decorrentes, em regra, da produção feita, no exterior, da Lex Maritima. "Tais usos e costumes carecem," afirma, "de filtragem jurídica crítica que contemple a eficácia dos interesses, pela ordem, dos usuários brasileiros de transporte aquaviário e dos carriers de nacionalidade brasileira, também chamados na terminologia regulatória setorial de EBN's (Empresas Brasileiras de Navegação)".

22 No original: "Volver a lo que nosotros llamamos el 'viejo corazón del derecho comercial', siempre renovado, en un doble esfuerzo: un derecho substancial más simple, 
E arremata o autor em outro estudo (2010):

Claro que tudo é ilusório se a reparação jurisdicional não for oportuna, o que implicaria voltar ao velho coração do direito comercial: os usos e costumes como ética dos negócios, e a justiça rápida para dissuadir o descumprimento planejado, para restabelecer a relação afetada e devolver a riqueza ao circuito econômico (Richard, 2010, p. 144).

Assim, numa primeira impressão, é autorizado entender que o velho coração do direito comercial se encontra num direito objetivo mais enxuto e eficaz, permeado de maior autonomia da vontade, limitada apenas pela necessidade de regulação e pelo interesse público, fazendo-se acompanhar de uma Justiça rápida e eficiente.

Voltar ao velho coração do direito comercial seria, nas palavras do professor Efraín, adotar os usos e costumes como ética dos negócios, a fim de devolver-se a riqueza ao mercado ${ }^{23} \mathrm{e}$ à sociedade.

Esta afirmação parece encontrar apoio não só no artigo 25 do regulamento 738/1850 (nosso velho direito comercial), mas também em João Eunápio Borges (1964) quando este explica como seriam tais usos e costumes:

A exigência de serem os usos conformes aos princípios da boa-fé e máximas comerciais, traduzida em termos jurídicos, significaria simplesmente a proibição de usos contrários a normas ou princípios de ordem pública. Mas,

configurando lo que llamamos la 'economía del Derecho', con menos normas pero más efectivas, librando las conductas a la autonomía de la voluntad en cuanto no infrinja el orden social pretendido, y cuando se adviertan desvíos o la necesidad de regulación disponer de técnicas normativas pluscuamperfectas. $\mathrm{Al}$ mismo tiempo una justicia inmediata, o por lo menos más eficiente"... (Richard, 2002).

23 Por oportuno, observe-se que Paula Forgioni (2009, pp. 189-199 e 225-228), inspirada em Asquini, encara o mercado - este emaranhado de relações contratuais - como fenômeno "poliédrico", uno, mas dotado de várias facetas, interdependentes entre si, onde identifica quatro perfis ou dimensões, a saber, o econômico (mercado abrangendo o conjunto das relações existentes entre os agentes que nele atuam e também o produto dessa interação), o político (mercado como objeto de intervenção exógena formatada pelo direito, ou seja, de decisões políticas e implementação de políticas públicas), o social (o mercado tem função social, derivada de normas constitucionais - artigo 219 CF, que também o formatam) e, por fim, o jurídico (compreende o conjunto de regras e princípios que pauta o comportamento dos agentes econômicos). Vê-se, portanto, que o mercado é fenômeno complexo, tecido pelos agentes econômicos.

Esta obra está bajo una Licencia Creative Commons

Atribución-NoComercial-SinDerivar 4.0 Internacional, IIJ-UNAM.

Boletín Mexicano de Derecho Comparado, núm. 151, pp. 227-262. 
evidentemente, tem ela um alcance de ordem moral, de sorte que os usos comerciais não possam ser admitidos, se, embora lícitos, não forem honestos (Borges, 1964, p. 75).

Desta forma, entende-se que, num plano ideal, onde se tivesse boa-fé, honestidade ${ }^{24}$ e respeito às leis, seria possível, sim, voltarmos ao velho coração do direito comercial, adotando-se os usos e costumes como ética dos negócios, ${ }^{25}$ desde que se contasse também com uma Justiça rápida e capaz de promover o reequilíbrio das relações jurídicas atingidas por eventuais comportamentos desviantes.

Contudo, a realidade brasileira é muito menos romântica. Nesse sentido, Eduardo Goulart Pimenta (2005) aponta um drama muito comum em nosso país:

Um grande número de pessoas não absorvidas pelo mercado de trabalho ou que de repente se veem desempregadas, buscam no exercício da atividade empresarial, por conta própria, uma forma de manter dignamente a si próprio e a sua família. Essa massa de trabalhadores passa a exercer micro ou pequenos empreendimentos empresariais sob a forma de empresários individuais - muitas vezes à margem das formalidades e requisitos legais - ou por meio de sociedades limitadas. Estas últimas, por sua vez, apresentam, via de

24 Quanto a este aspecto, Gustavo Tepedino e Anderson Schreiber (2003, p. 149) advertem que, "em relações não caracterizadas pela vulnerabilidade de qualquer das partes, é imprescindível conceber a boa-fé na sua real extensão: como princípio que exige lealdade e honestidade, impondo deveres de colaboração que são condicionados e limitados pela função social e econômica do negócio celebrado. Isto se torna ainda mais evidente naquelas relações de ordem mercantil" (destaque nosso).

25 Ao que parece, Bruno Nubens Miragem (2004, pp. 35 e 36) também autoriza esta compreensão em seu instigante estudo ao consignar que "nas obrigações de natureza empresarial, a tendência de valorização da confiança observa-se em dois planos. De um lado, como reação à tendência de flexibilização, como necessidade consequente do reconhecimento de standards com força jurídica e aceitação pelos indivíduos envolvidos. De outro, como espécie de garantia necessária à velocidade atual dos negócios, que estimulam, no âmbito jurídico, a elevação da importância dos usos e costumes como fonte das obrigações e, neste sentido, a proteção das expectativas legítimas geradas a partir do respeito aos mesmos. O reforço da confiança consistirá no reconhecimento, pelo direito empresarial, de efeitos jurídicos próprios às expectativas legítimas e aos deveres oriundos da boa-fé, matriz valorativa do direito privado, consagrada internamente no novo Código Civil, bem como pelo retorno dos usos e costumes comerciais como fonte do direito, recuperando seu papel eclipsado, eventualmente, pelas aspirações de regulação exaustiva do século vinte". 
regra, o número mínimo de integrantes e, na maioria dos casos, têm seu capital quase totalmente concentrado nas mãos de um único sócio que, motivado pelas circunstâncias mencionadas constitui a pessoa jurídica.

O que se percebe, entretanto, é que o destino econômico de tais empreendimentos tende, quase de forma inarredável, ao insucesso. Sem a devida capacidade técnica e orientação administrativa, vitimados pela excessiva burocracia e tributação, tais empresários acabam por gerir de forma inadequada a atividade que, em pouco tempo, já se mostrará inviabilizada economicamente (Pimenta, 2005, p. 6).

Assim, crise econômica, burocracia, excessiva carga tributária e insegurança jurídica não apenas desestimulam, mas inibem realmente o desenvolvimento do comércio e do mercado. Entretanto, se considerarmos as leis como normas exógenas que também fazem parte da ordem jurídica do mercado, vocacionadas à realização de políticas públicas, e deixando de lado um perfil ultrapassado de direito comercial, como se o mercado funcionasse bem livremente - ilusão que devemos rechaçar - seria possível ver naquelas, as leis, catalisadores de relações econômicas, capazes de reduzir custos de transação, aumentar o grau de segurança jurídica e até mesmo eliminar falhas de mercado (Forgioni, 2009, p. 234).

Em tempos de globalização e de uma nova lex mercatoria - conjunto de regras, princípios e costumes oriundos da prática comercial, sem vinculação a qualquer direito nacional ${ }^{26}$ em que se busca segurança jurídica para o comércio, especialmente o internacional, novas soluções precisam ser pensadas para dar fim à crise que atinge os países atual-

26 O jurista Manoel Justino Bezerra Filho, em palestra proferida no Congresso internacional intitulado "O Estado, A Empresa e o Mercado - Novas Tendências de Direito Econômico", promovido pela Faculdade de Direito da Universidade de São Paulo, consignou que "à semelhança da Revolução Comercial e da decorrente globalização dos séculos XV/XVI, estamos hoje diante do retorno de uma nova forma de 'Lex Mercatoria', que se poderia entender como a coletânea de regras formadas a partir do costume das grandes empresas, aplicando-se a qualquer atividade empresarial e a qualquer empresário, independentemente do lugar no qual o fato tenha ocorrido e independente também da nacionalidade dos envolvidos no litígio a ser solucionado". Assim é porque o comércio internacional, ensina-nos Maristela Basso (1996, p. 207), "exige negócios mais rápidos e seguros, impostos menores, lucros maiores, e desta realidade inexorável surge um conjunto de normas não estatais, um direito transnacional do comércio, ao qual se convencionou chamar nova lex mercatoria: usos e costumes nos quais a prática internacional se conforma" (destaque nosso).

Esta obra está bajo una Licencia Creative Commons

Atribución-NoComercial-SinDerivar 4.0 Internacional, IIJ-UNAM.

Boletín Mexicano de Derecho Comparado, núm. 151, pp. 227-262. 
mente. Exige-se, para tanto, uma nova ordem econômica internacional mais harmoniosa, um denominador comum para a legislação comercial mundial.

Atente-se, porém, para o fato de que a nova lex mercatoria não se confunde com a antiga, ou seja, a lex mercatoria de origem medieval não guarda efetiva identificação com o novo fenômeno globalizante contemporâneo, diretamente relacionado à internacionalização da economia e descodificação do direito. Frederico Glitz (2012) bem o explica:

Ainda que se pudessem localizar entre a "antiga Lex mercatoria" e o novo fenômeno normativo paralelos interessantes, não se pode duvidar de suas notáveis diferenças. De um lado, ambos os movimentos seriam formados por usos, usos comerciais e Direito espontâneo uniforme e se prestariam a superar dificuldades decorrentes da estrita aplicação da técnica de conflito de leis. Por outro lado, o movimento contemporâneo não só teria fontes próprias, como método de solução de controvérsias específica, à margem do sistema estatal e internacional. Além disso, ao contrário da Lex mercatoria medieval, o movimento contemporâneo não seria totalmente espontâneo nem desinteressado, nem os costumes reconhecidos e julgados pelos seus produtores... Some-se a isso o fato de os momentos históricos serem distintos. Enquanto a lex mercatoria medieval se apresenta em um momento de fragmentação do império romano e sua substituição, pelo menos na Europa ocidental, por um sistema feudal de produção; o fenômeno contemporâneo se insere em um momento de internacionalização da economia, descodificação do Direito comercial e mudança da postura do Estado frente à atividade econômica (Glitz, 2012, p. 126-127).

Conforme lição de Ana Paula Martins Amaral (2002, p. 88), três correntes tentam explicar a nova lex mercatoria enquanto ordem jurídica singular, autônoma e aplicável especificamente nos negócios e transações internacionais. A primeira delas, a considera um (a) direito anacional ou ordem jurídica autônoma, criada espontaneamente pelos agentes do comércio internacional, cuja existência independe dos ordenamentos jurídicos estatais; para a segunda (b), a lex mercatoria seria uma alternativa para a ordem jurídica aplicável, por constituir um corpo suficiente de regras jurídicas que permitem decidir um litígio entre agentes do comércio internacional; por fim, a terceira corrente (c) entende que a lex mercatoria se destinaria a complementar o direito nacional aplicável, 
constituindo-se numa consolidação dos usos e costumes do comércio internacional. ${ }^{27}$

Refletindo sobre a nova lex mercatoria enquanto moderno direito espontâneo do comércio internacional, essencialmente consuetudinário e que desconhece fronteiras, María Silvia Gómez Bausela (2003) afirma que os usos e costumes são a mais importante fonte de produção jurídica daquele ordenamento, gerado pela força das necessidades do comércio internacional. Segundo a autora,

Este novo ordenamento surgiu apesar das assimetrias e diferenças assinaladas e se mostra como um direito autônomo do comércio, gerado pela força de suas necessidades, que se tem desenvolvido e que o continua fazendo independentemente dos sistemas jurídicos nacionais. Assim, pois, a aceitação desta ordem jurídica particular é fator de estabilidade, de cooperação e de segurança jurídica no tráfego comercial. Implica a revalorização dos usos e costumes "como também da ética dos negócios" e da "justiça imediata". Essa revalorização é um "voltar ao coração do direito comercial". Os usos e costumes são a fonte mais importante de produção da nova lex mercatoria. Compreende desde a simples habitualidade individual até o próprio costume jurídico (Bausela, 2003, pp. 10 e 11). ${ }^{28}$

27 De acordo com Jete Fiorati (2004, p. 19), "foi Berthold Goldman quem, em 1964, observando a existência desse direito costumeiro internacional, nascido das práticas comerciais internacionais, trouxe à tona a doutrina da nova lex mercatoria, em trabalho publicado nos Archives de Philosophie du Droit, n ${ }^{\circ}$ 09, intitulado Frontières du droit et lex mercatoria". Nesse estudo, informa a autora, Goldman "lançou as bases para uma discussão sobre a nova lex mercatoria e sua caracterização como fonte do direito do comércio internacional". Na mesma linha, Valério Mazzuoli (2002, pp. 70 e 79) atribui a Berthold Goldman o mérito de ter detectado a existência de um direito costumeiro internacional, nascido das práticas comerciais internacionais relacionadas a venda, crédito, transporte e sociedades, estudando-o detidamente e lançando as bases para a sua compreensão como fonte do direito do comércio internacional.

28 Na verdade, a doutrina diverge um pouco com relação às fontes da nova lex mercatoria. Quanto a este aspecto, Maristela Basso (1998, p. 14) esclarece que, além do direito convencional —os tratados bi ou multilaterias celebrados entre os Estados — são fontes do comércio internacional "o chamado direito costumeiro, isto é, os usos e costumes peculiares aos mais variados setores das atividades mercantis, e que se tornam uma prática constante e geral na grande maioria dos mercados. Também deve-se referir, as decisões arbitrais, principalmente aquelas proferidas pelas mais importantes instituições de arbitragem internacionalmente reconhecidas, como a Câmara de Comércio Internacional de Paris - CCI". Para Pedro Pontes de Azevedo (2006, p. 98), entretanto, "as fontes da nova lex mercatoria são os contratos-tipo, as condições gerais de compra e venda, as condições

Esta obra está bajo una Licencia Creative Commons

Atribución-NoComercial-SinDerivar 4.0 Internacional, IIJ-UNAM.

Boletín Mexicano de Derecho Comparado, núm. 151, pp. 227-262. 
Por conta desta afirmação, entende-se que a mencionada jurista foi quem melhor compreendeu e traduziu o pensamento de Efraín H. Richard, fazendo-o com maestria.

Voltar ao velho coração do direito comercial - o que parece bom, mas não se crê possível - seria, hoje, o equivalente a seguir uma receita ancestral, na qual já se confiou para curar uma velha doença, bastante diferente, porém, dos novos e sofisticados males decorrentes da globalização e da modernidade. Isto porque, a rigor, a nova lex mercatoria não poderia ser tão costumeira quanto foi a antiga, e nem aplicada de forma tão célere, por mais desejável isto fosse.

Esta compreensão encontra amparo em estudo de João Luís Nogueira Matias (2000, pp. 111 e 112), para quem a nova lex mercatoria foi chamada a exercer um papel de direito comum do comércio internacional, não podendo, por isso, ser de natureza costumeira, como o antigo jus mercatorum, mas de natureza legislativa, para colocar os Estados diante de suas responsabilidades e obrigações. Assim, embora fascinante, careceria de aplicação prática, principalmente por não possuir uma perfeita sistematização, carecendo também de obrigatoriedade, motivo pelo qual ainda não atenderia, em seu estágio atual, às expectativas dos operadores econômicos. Nem por isso, entretanto, deixa de reconhecer o autor que a lex mercatoria goza, muitas vezes, de uma efetividade bem maior do que a legislação interna ou mesmo internacional.

Outra questão que se descortina hodiernamente é a possibilidade ou não de utilização da lex mercatoria como forma de resolução dos litígios no comércio internacional, contrapondo-se os que defendem a incompatibilidade desta com o direito nacional àqueles que advogam a tese da sua

gerais do Conselho de Assistência Econômica Mútua (Comecon), os Incoterms e as leis uniformes", que se apesentam como suporte para a interpretação e consolidação das regras costumeiras que compõem a lex mercatoria. De outra banda, alerta Ana Paula Martins Amaral (2002, p. 90) que os componentes da lex mercatoria até poderiam ser aceitos como parte integrante dos contratos internacionais, mas não poderiam figurar como um novo direito. Seriam, pois, considerados apenas usos e costumes do comércio internacional, que a exemplo dos Incoterms, são utilizados nos contratos com base na autonomia da vontade. Dessa forma, são aceitos pela justiça dos Estados, mas não se apresentam como parte de um novo direito considerado supranacional. Segundo a autora, "a autonomia da vontade seria assim o acesso permitido aos usos e costumes internacionais para figurarem nos contratos, mas não os validariam como direito e sim como complemento do direito nacional aplicável ao caso concreto". 
aplicação consentânea com o direito emanado do Estado. É o que explica Pedro Pontes de Azevedo (2006), no trecho abaixo:

Para a primeira corrente, o fato de a lex mercatoria não ser uma lei formal, que não se apoia em um sistema legal, retiraria qualquer autoridade de sua base jurídica. Assim, não seria possível a resolução de conflitos tendo por base os seus preceitos, ante a ausência da chancela estatal. Postulam ainda pela ineficácia da lex mercatoria em face da ausência de princípios gerais comuns a todos os Estados-nações, o que gera a incompletude do sistema, possibilitando, inclusive, a existência de lacunas e, via de consequência, a prolação de decisões arbitrárias e conflitantes, em casos análogos. Já os que defendem a aplicação da lex mercatoria, baseiam-se no argumento de que todos os sistemas podem se apresentar lacunosos, não deixando de ter aplicabilidade por tal razão. Ademais, soluções conflitantes existem em qualquer ordenamento jurídico, por mais positivadas que estejam as normas jurídicas. Acrescentam ainda que as questões relacionadas ao comércio internacional apresentam-se como de grande complexidade, o que quase sempre impossibilita um julgamento técnico satisfatório por intermédio do Poder Judiciário, sendo mais propício o estabelecimento de soluções via juízo arbitral, composto por especialistas nas áreas especificamente tratadas nos pactos ou contratos empreendidos nas relações comerciais supranacionais. Entendemos ser mais consentâneo com a realidade do mercado global o entendimento segundo o qual a lex mercatoria é aplicável quando as partes assim dispuserem, segundo o princípio que lhes assegura a autonomia da vontade quando da negociação (Azevedo, 2006, p. 98). ${ }^{29}$

29 Ainda acerca da questão, preciosa lição nos é ofertada por Hermes Marcelo Huck (1992, pp. 228 e 229), para quem "a proposta de uma nova lex mercatoria tem inegavelmente um objetivo prático de valor considerável, buscando dar maior eficiência ao comércio internacional e, principalmente, solucionar com rapidez as pendências nele surgidas. Lex mercatoria e arbitragem comercial internacional são os remédios mais frequentemente buscados como solução para os grandes problemas surgidos no comércio internacional”, alerta o autor. Adverte, contudo, que "o reconhecimento de que os direitos nacionais prevalecem no comércio entre nações, bem como a constatação de que a lex mercatoria ainda não alcançou os contornos de um direito supranacional autônomo e autocontido, não são suficientes para decretar o fracasso das tentativas de uniformização das regras jurídicas para o comércio extra-fronteiras". Admite, porém, que as decisões arbitrais, quando fundamentadas nos princípios supranacionais do comércio internacional, podem enfrentar a mesma dificuldade experimentada por sentenças estrangeiras que não encontrem reconhecimento e execução no seio de um tribunal nacional. Isto porque, prossegue o jurista, "decisões arbitrais estribadas na lex mercatoria, buscando apenas a uniformização redutora das normas comerciais, muitas vezes concedem pouca importância a conceitos essenciais

Esta obra está bajo una Licencia Creative Commons

Atribución-NoComercial-SinDerivar 4.0 Internacional, IIJ-UNAM.

Boletín Mexicano de Derecho Comparado, núm. 151, pp. 227-262. 
Entende-se, contudo, que a imposição vinculativa de uma nova lex mercatoria, apartada dos controles e limitações inerentes à soberania estatal, pode ser desastrosa, sobretudo se desatenta às desigualdades econômicas entre as nações, motivo pelo qual parece razoável a concepção do autor mencionado, no sentido de que a lex mercatoria é aplicável quando as partes assim o dispuserem, segundo o princípio que lhes assegura a autonomia da vontade quando da negociação realizada.

Por outro lado, e, numa perspectiva do direito interno, não se acredita que a aprovação de um novo Código Comercial para o Brasil serviria realmente para impulsionar o processo de restauração dos valores do direito empresarial. Afinal, ao que parece, poucos são os que anseiam por tal diploma. Melhor seria, talvez, pôr de lado o que é arcaico e remendar o velho texto, como fizeram outras nações. Atualizar-lhe a redação, sem estragá-lo ou retirar-lhe a alma, avançando para a construção de um direito objetivo mais enxuto e eficaz, com mais espaço para a autonomia da vontade, limitada tão somente pela efetiva necessidade de regulação e pelo verdadeiro interesse público, acompanhado de uma justiça célere e especializada.

Contudo, é de se reconhecer que precisamos mesmo modernizar nossa legislação empresarial, a fim de que o país se torne mais competitivo na disputa por investimentos. ${ }^{30}$ Nesse sentido, parece correto o prof. Fábio Ulhoa Coelho (2011, p. 14) quando diz que "normas claras e adequadas,

como justiça e equidade", de sorte que "não se pode aceitar como sendo objetivo um direito (e uma jurisdição como a arbitragem) orientado exclusivamente pelas frias regras mercantis, desatento às particularidades políticas e econômicas que o comércio internacional reflete, muito especialmente no tocante às desigualdades econômicas entre as nações, desigualdades essas que podem ser minimizadas com o uso adequado das práticas do comercio internacional".

30 Nem por isso, se está a defender uma gestão neoliberal de Estado, mas um equilíbrio de forças produtivas capazes de alavancar o desenvolvimento nacional, pois como bem observou Leda Paulani (2006, p. 80), "a gestão neoliberal do Estado implica conduzi-lo como se fosse um negócio, mas o resultado é o inverso do que ocorre quando essa racionalidade é aplicada ao setor privado. Em vez do acúmulo de recursos e da reprodução ampliada do capital público, temos dilapidação dos recursos do Estado, encolhimento de seu tamanho, atrofiamento do espaço econômico público, em uma palavra: espoliação". Desta feita, o Estado não tem que ser grande, inchado, mas tem que ser forte. Na verdade, prossegue a autora, "ele tem de ser extremamente forte, no limite violento, para conduzir os negócios de Estado da forma mais adequada possível de modo a preservar e contemplar grupos de interesse específicos". 
estabelecidas na justa medida da distribuição da proteção dos interesses, têm maior chance de granjear o respeito dos agentes econômicos e de serem aplicadas pelo Poder Judiciário".

Ao fim destas despretensiosas considerações, reconhece-se a autoridade daquele grande jurista argentino, Efraín Hugo Richard, que recentemente sintetizou de forma irrepreensível:

O direito deve garantir a convivência e a paz social. O direito comercial deve facilitar e promover a atividade produtiva e o trabalho digno, desestimulando os descumprimentos. Segurança jurídica, previsibilidade e solução rápida dos conflitos, "com boa-fé observada e verdade sabida" são os pilares de um sistema jurídico equilibrado para o desenvolvimento do país e de sua comunidade (Richard, 2014, p. 29).

Eis o que importa.

\section{GONCLUSÃO}

A esta altura, não é difícil entender que uma das funções mais importantes do direito, além da solução de conflitos, consiste em viabilizar o desenvolvimento, induzindo o comportamento dos agentes econômicos de modo a criar um ambiente institucional favorável à maior eficiência do mercado.

Para tanto, exige-se flexibilidade, dinamismo e até mesmo certa dose de informalidade, quando esta for admissível, o que não se consegue com um ordenamento jurídico excessivamente rígido, impermeável ou mesmo distanciado das práticas sociais.

Daí a contribuição que usos e costumes impregnados de força normativa podem oferecer aos sistemas jurídicos, mesmo àqueles que se acreditam autossuficientes, diante de uma realidade cada vez mais dinâmica e complexa, para que tais ordenamentos possam atender continuamente às necessidades sociais, sobretudo no que diz respeito às relações contratuais que, por sua própria natureza, sofram constantes modificações no tempo e no espaço.

Os usos e costumes, oriundos que são de práticas sociais dotadas de continuidade, uniformidade, moralidade e conformidade com a lei, revelam importância e utilidade que não se limitam a um determinado ramo do direito, ou mesmo ao chamado direito privado, mas a todo o direito.

Esta obra está bajo una Licencia Creative Commons

Atribución-NoComercial-SinDerivar 4.0 Internacional, IIJ-UNAM.

Boletín Mexicano de Derecho Comparado, núm. 151, pp. 227-262. 
Por se originarem de práticas que se disseminaram espontaneamente, podem oferecer uma solução mais tendente à paz social e à acomodação de interesses conflitantes.

É nesse contexto que se destaca a importância dos usos e costumes na regulação dos negócios empresariais, pois é sobre a prática costumeira e habitual que se assenta a credibilidade do tráfico negocial. É nos usos e costumes que fica registrado o padrão informal de trabalho do empresariado e é neles que se encontra o repositório de boas práticas para a regulação das relações empresariais.

Aqui, entende-se que um conjunto forte e organizado de normas costumeiras, por vezes afastando a aplicação de preceitos legais, o que se observa mais facilmente em mercados com pequeno número de agentes - mas homogêneos entre si - pode operar com sucesso, chegando ao ponto de tornar desnecessária e mesmo indesejável a intervenção estatal, quase sempre artificial e heterônoma. Isto reforçará a segurança jurídica e, indiretamente, o próprio direito objetivo. Afinal, suprindo mais adequadamente as lacunas da legislação empresarial, promovendo a integração contratual e facilitando sua interpretação, os usos e costumes comerciais garantiriam, com mais efetividade e permanência, a atualidade do ordenamento.

Infelizmente, com a crescente intervenção do Estado sobre a economia, como agente normativo, os órgãos da administração pública tomaram para si a tarefa de regular as minúcias das relações econômicas privadas. E, por isso, os costumes porventura criados (ou em criação) foram percebidos e assimilados pelo ente normatizador, sendo incorporados nas normas por ele baixadas. Dessa forma, o poder público passa a influenciar, inclusive, o mecanismo de "seleção natural" dos costumes, o que não se afigura correto.

Ora, enquanto o Estado se sentir livre para editar atos normativos de cunho econômico, muitas vezes de forma excessiva, minuciosa e dissociada das reais necessidades de seus destinatários, interferindo até mesmo na formação de um costume ou prática comercial, não haverá espaço para um desenvolvimento "natural" da economia. Ao contrário, estar-se-á alimentando o velho cordão umbilical que nos liga ao tradicional capitalismo de Estado brasileiro.

A rigor, o instituto dos usos e costumes sempre esteve presente em nosso ordenamento, ora com mais força, como no passado, ora com menos 
intensidade, mostrando-se respeitável a intenção porventura manifestada em um novo e eventual diploma comercial no sentido de promover a revalorização dos usos e costumes, como forma de aperfeiçoar contratos e negócios. Curioso observar, entretanto, como o termo costume se revelou polissêmico para o direito.

Contudo, forçoso é reconhecer a aplicabilidade ainda limitada dos usos e costumes no ordenamento pátrio, considerando a nossa já enraizada tradição codificante, sempre a reclamar, compreensivelmente, sistematização e obrigatoriedade que, em uma nova ordem econômica mundial, precisa necessariamente ser flexibilizada para atender às expectativas dos mais variados agentes produtivos.

Em contrapartida, os usos e costumes foram revigorados em função do fenômeno contemporâneo e globalizante da nova lex mercatoria, um direito transnacional do comércio, que tem naqueles uma de suas principais fontes.

Destaque-se, entretanto, que a imposição vinculativa de uma nova lex mercatoria aos países, apartada dos controles e limitações inerentes à soberania estatal, pode ser desastrosa, sobretudo se desatenta às desigualdades econômicas entre as nações, motivo pelo qual parece razoável a compreensão no sentido de que a lex mercatoria é aplicável quando as partes assim o dispuserem, segundo o princípio que lhes assegura a autonomia da vontade quando da negociação realizada.

Por todo o exposto, não é ir longe demais afirmar que, num plano ideal, onde se tivesse boa-fé, honestidade e respeito às leis, seria possível, sim, voltar ao velho coração do direito comercial, adotando-se os usos e costumes como ética dos negócios, desde que se contasse também com uma justiça rápida e capaz de promover o reequilíbrio das relações jurídicas atingidas por comportamentos desviantes.

Porém, a realidade brasileira é bem mais hostil. Assim, por mais justas tenham sido as palavras do reconhecido jurista portenho e retas suas intenções, a verdade é que ainda estamos muito distantes de ter um regime jurídico verdadeiramente democrático e suficientemente preparado para autorizar a aplicação madura e saudável, generalizada e atual, dos usos e costumes comerciais. 


\section{REFERÊNCIAS}

Amaral, Ana Paula Martins, "Lex mercatoria e autonomia da vontade", Revista do Instituto de Pesquisas e Estudos, v. 34, abr./jul. 2002.

Argentina, Código Civily Comercial de la Nación, 2a. ed., Ciudad Autónoma de Buenos Aires, Infojus, 2016.

Azevedo, Pedro Pontes de, "A lex mercatoria e sua aplicação no ordenamento jurídico brasileiro",prim@facie,n. 9, jul./dez. 2006.

BASSO, Maristela, "A autonomia da vontade nos contratos internacionais do comércio", Revista da Faculdade de Direito da UFRGS, v. 12, 1996.

BASSO, Maristela, "Introdução às fontes e instrumentos do comércio internacional" Revista da Faculdade de Direito da UFRGS, v. 11, 1998.

Gómez Bausela, María Silvia, "Algunas consideraciones acerca de la nueva lex mercatoria y la globalización", Revista de la Facultad de Ciencias Jurídicas y Sociales, Santa Fé, Rep. Argentina, 2003.

BeviláQUA, Clóvis, Teoria geral do direito civil, 2a. ed., Campinas, RED Livros, 2001.

Borges, João Eunápio, Curso de direito comercial terrestre, 2a. ed., Rio de Janeiro, Forense, 1964.

Castro Junior, Osvaldo Agripino de, "Principais aspectos do direito marítimo e sua relação com a lex mercatoria e lex marítima", Revista Seqüência, v. 31, n. 61, 2010.

Catapani, Márcio Ferro, "Os costumes mercantis e o seu assentamento pela JUCESP”, Revista de Direito Mercantil, Industrial, Econômico e Financeiro, n. 158, abr./jun., 2011.

Coelho, Fábio Ulhoa, O futuro do direito comercial, São Paulo, Saraiva, 2011.

Dinamarco, Cândido Rangel, Instituições de direito processual civil, v. 1. 7a. ed., São Paulo, Malheiros, 2013.

Diniz, Maria Helena, Código civil anotado, 15a. ed., São Paulo, Saraiva, 2010.

FÉRES, Marcelo Andrade, "Breve registro da experiência francesa da sociedade por ações simplificada", Revista Síntese de Direito Civil e Processual Civil, São Paulo, n. 55, set./out., 2008.

FIORATI, Jete Jane, "A lex mercatoria como ordenamento jurídico autônomo e os Estados em Desenvolvimento", Revista de Informação Legislativa, Brasília, a. 41, n. 164, out./dez. 2004. 
Forgioni, Paula Andrea, A evolução do direito comercial brasileiro: da mercancia ao mercado, São Paulo, Editora Revista dos Tribunais, 2009.

GLITZ, Frederico E. Z., "Apontamentos sobre o conceito de lex mercatoria", Revista Jurídica, Curitiba, v. 1, n. 28, 2012.

Gomes, José Jairo, Direito civil: introdução e parte geral, Belo Horizonte, Del Rey, 2006.

Gonçalves, Carlos Roberto, Direito civil brasileiro, v.1: parte geral, 10a. ed., São Paulo, Saraiva, 2012.

Huck, Hermes Marcelo, "Lex mercatoria - horizonte e fronteira do comércio internacional", Revista da Faculdade de Direito da USP, v. 87, 1992.

LOSANO, Mario Giuseppe, Os grandes sistemas jurídicos: introdução aos sistemas jurídicos europeus e extra-europeus, São Paulo, Martins Fontes, 2007.

MATIAS, João Luís Nogueira, "Lex mercatoria e contratos comerciais internacionais", Revista da Procuradoria Geral do Município de Fortaleza, ano 7, v. 8, Fortaleza, 2000.

Matias, João Luís Nogueira; RochA, Afonso de Paula Pinheiro, "Atuação estatal na ordem pública e privada", Nomos - Revista do Curso de Mestrado em Direito da UFC, Fortaleza, 2006.

Mazzuoli, Valério de Oliveira, "Lex mercatoria e o comércio internacional: unidade ou pluralismo de ordens jurídicas? A concepção de Berthold Goldman", Revista Furídica UNIGRAN, v. 4, n. 8, 2002.

Mello, Dirceu de, "O costume no direito brasileiro", Revista fustitia, v. 64, n. 197, jul./dez., 2007.

Miragem, Bruno Nubens Barbosa, "Do direito comercial ao direito empresarial. Formação histórica e tendências do direito brasileiro", Revista da Faculdade de Direito da UFRGS, n. 24, 2004.

Monteiro, Washington de Barros, Curso de direito civil, v. 1. São Paulo, Saraiva, 1995.

NÁufel, José, Novo Dicionário furídico Brasileiro, 3a. ed., Rio de Janeiro, José Konfino Editor, 1963.

NERY JÚNIOR, Nelson, Código de processo civil e legislação processual civil extravagante em vigor, São Paulo, Editora Revista dos Tribunais, 1994.

Noronha, E. Magalhães, Direito penal, v. 1. São Paulo, Saraiva, 1979.

Nunes, Marcelo Guedes, "Princípio do reconhecimento dos usos e costumes comerciais", in Coelho, Fábio Ulhoa; Nunes, Marcelo Guedes (org.), Princípios do direito comercial, Faculdade de Direito, Pontifícia Universidade Católica-SP, São Paulo, 2011. Disponível em: http://wwre.

Esta obra está bajo una Licencia Creative Commons

Atribución-NoComercial-SinDerivar 4.0 Internacional, IIJ-UNAM.

Boletín Mexicano de Derecho Comparado, núm. 151, pp. 227-262. 
congressodireitocomercial.org.br/2011/images/stories/pdfs/gep2.pdf. Acesso em 15 jul. 2015.

Paulani, Leda Maria; Neves, Lúcia Maria Wanderley, "O projeto neoliberal para a sociedade brasileira: sua dinâmica e seus impasses", in Fundamentos da educação escolar do Brasil contemporâneo, Fiocruz, 2006.

PImenta, Eduardo Goulartigo, "A nova Lei de Falências e a recuperação de empresas", Quorum - Informativo da Livraria e Editora Del Rey, Belo Horizonte, ano II, n. 3, mai., 2005.

POletTI, Ronaldo, Introdução ao direito, 3a. ed., São Paulo, Saraiva, 2006.

QueIRogA, Daniel Silva, "A empresa e a intervenção estatal nos contratos empresariais: desvirtuamento ou necessidade de caracterização do empresário como consumidor?", Revista Brasileira de Direito Empresarial, v. 2, n. 1, jul./dez. 2015.

Ramos, André Luiz Santa Cruz, "Direito comercial ou direito empresarial? Notas sobre a evolução histórica do jus mercatorum", $R D C P C$, n. 40, mar./abr., 2006.

REQUião, Rubens, A preservação da sociedade comercial pela exclusão do sócio, tese (cátedra), Curitiba, Universidade Federal do Paraná, 1959.

RichaRD, Efraín Hugo, Ante la crisis: volver al corazón del derecho comercial, Córdoba, jul. 2002. Disponível em:<http://wwre.acaderc.org.ar/doctrina/ articulos/artcrisiscorazonderechocomercial>. Acesso em: 28 jun. 2015.

RichARD, Efraín Hugo, "El derecho en el siglo XXI (vision de um comercialista)", Revista de la Facultad de Derecho y Ciencias Sociales de Córdoba (UNC), vol. V, n. 2, nueva serie II, 2014.

Richard, Efraín Hugo, Perspectiva del derecho de la insolvência, Córdoba, Academia Nacional de Derecho y Ciencias Sociales de Córdoba, 2010.

Rocha, Olavo Acyr de Lima, "O costume no direito privado", Revista Justitia, v. 37, n. 90, jul./set., 1975.

Rocha Filho, José Maria; Rocha, Gustavo Ribeiro, Curso de direito comercial. Teoria geral da empresa e direito societário, 2a. ed., Belo Horizonte, D’Plácido, 2015.

Rohrmann, Carlos Alberto, Notas promissórias eletrônicas: uma análise do endosso eletrônico, Berkeley, CA, fev. 2000. Disponível em: < https://edisciplinas.usp.br/pluginfile.php/.../Nota\%20Promissoria\%20Eletronica.pdf?>. Acesso em: 11 jul. 2015.

Roxin, Claus, Introdução ao direito penal e ao direito processual penal, Belo Horizonte, Del Rey, 2007. 
Tepedino, Gustavo; Schreiber, Anderson, "Os efeitos da Constituição em relação à cláusula da boa-fé no Código de Defesa do Consumidor e no Código Civil", Revista da EMER7, v. 6, n. 23, 2003.

Verçosa, Haroldo Malheiros Duclerc, Curso de direito comercial, v. 4, São Paulo, Malheiros, 2011.

VINAGRE, Marta, "Costume: forma de expressão do direito positivo", $R e^{-}$ vista de Informação Legislativa, Brasília, a. 25, n. 99, jul./set. 1998. 